\title{
The Early Explorers of the Eastern Desert and the History of Monasticism: Sir John Gardner Wilkinson and James Burton
}

\section{Blaž Zabel and Jan Ciglenečki*}

\section{INTRODUCTION}

The mountainous Eastern Desert (Arabic: Al-Sahrāà Al-Sharqiyyah) that stretches between the Nile valley and the Red Sea is commonly regarded as the cradle of the Egyptian anachoretic tradition. ${ }^{1}$ According to the literary sources, it was in this region where the first "desert father" St. Anthony took refuge in the 3 rd and 4 th century AD. Despite the importance that the Eastern Desert had in early monastic literature, especially in influential works such as Vita Antonii by St. Athanasius and Vita Pauli by St. Jerome, relatively few remains of the ancient anachoretic establishments can be found in the region today.

* Durham University, Department of Classics and Ancient History, 38 N Bailey, Durham DH1 3EU, UK; blaz.zabel@durham.ac.uk; University of Ljubljana, Department of Philosophy, Aškerčeva 2, sI-10oo Ljubljana; ciglenecki.jan@ gmail.com.

1 The authors would like to thank Ronald E. Zitterkopf for his help with navigating through James Burton's archive, and to the Bodleian Libraries (Oxford), British library (London), and Royal Geographical Society (London) for granting access to the archival material. 
An essential source of information in this regard are the works of early explorers and adventurers who traveled to the area and had the chance to observe and record many of the monuments now destroyed or severely damaged. To this end, our study analyzes the published papers as well as the unpublished personal diaries, notes, sketches, and maps of two crucial early explorers of the Eastern Desert, Sir John Gardner Wilkinson and James Burton. Both were true pioneers who documented several nowadays little-known anachoretic sites. Their notes are of utmost importance for the history of monasticism in the Eastern Desert.

\section{SIR JOHN GARDNER WILKINSON, THE FATHER OF BRITISH EGYPTOLOGY}

Sir John Gardner Wilkinson (1797-1875) is best known for his work as an Egyptologist. ${ }^{2}$ During his long and productive career, he traveled widely around Egypt and Nubia, documenting important ancient Egyptian archaeological sites, among them, most famously, Thebes, the Valley of the Kings, and the Tombs of the Nobles on the hill of Shaykh 'Abd al-Gurna. Alongside the popular Handbook for Travellers in Egypt (1847), he wrote several essential and ground-breaking studies on ancient Egypt, such as Topography of Thebes and General View of Egypt (1835) and the renowned Manners and Customs of the Ancient Egyptians (1837), which are still considered one of the earliest works of modern Egyptology. Alongside his archaeological and historical work, Wilkinson is notable also for his contribution to the decipherment of Egyptian hieroglyphics by Champollion, for he provided the French scholar with numerous transcripts and later even corrected some of his translations. His interest in ancient Egypt, his numerous travels and documentations, his archaeological work, and his influential publications brought Wilkinson international fame. Even today, as Dawson and Uphill wrote in their Who Was Who in Egyptology, Wilkinson is considered to be "the real founder of Egyptology in Great Britain" (figure 1). ${ }^{3}$

2 For the life and work of Wilkinson see: Thompson, Sir Gardner Wilkinson and His Circle; "The Sir Gardner Wilkinson Papers"; "Sir John Gardner Wilkinson in Gower"; "Sir Gardner Wilkinson's House at Sheikh Abd El Qurna”; and Wonderful Things (especially pages 149-172); Jasanoff, Edge of Empire; Colla, Conflicted Antiquities. Cf. Thompson, "Osman Effendi"; and "Edward William Lane in Egypt." 
While Wilkinson is today known mostly for his work on ancient Egyptian civilization, his interests were much broader. Besides all aspects of archaeology and history, these interests also included anthropology, ethnography, botany, zoology, geography, cartography, etc. Wilkinson first visited Egypt in 1821 on the recommendation of his mentor, a prominent classical scholar of the time, Sir William Gell. ${ }^{4}$ This was his first trip to the country which impressed him greatly; so much so that he stayed continuously for the next twelve years. Soon, Wilkinson met another British explorer and adventurer, James Burton (1786-1862), who befriended him and invited him to join his expeditions to the Eastern Desert in 1823 (figure 2). Over his twelve years' stay, Wilkinson traveled often and far, to Fayum, the Western Oases, the Eastern Desert, and up and down the Nile Valley. During his travels, he conducted thorough surveys and produced numerous detailed sketches of the ancient sites, monuments, and inscriptions, many of which are now lost or destroyed. The discoveries he made and the documents he produced were of immense importance for the development of Egyptology and are still considered a valuable source for modern scholars.

Wilkinson returned to England only in 1833, after having spent a dozen years in Egypt, and started working on publishing his results, including his Manners and Customs of the Ancient Egyptians, which brought him international fame. He returned to Egypt in 1841, also intending to update data for his (soon-to-be) best-seller Handbook for Travellers in Egypt, but left rather soon to avoid the summer heat. In 1848, Wilkinson again traveled to Egypt to undertake further expeditions. Even though he stayed only during the winter, he journeyed down the Nile to present-day Sudan, taking extensive notes. This was his last productive trip to Egypt, even though he revisited the country in 1855 intending to study the Christian remains. His plans, however, came to an end when a sunstroke hit him, and his travel plans were hindered. The rest of his life he spent in England and Europe, and his interests slowly diverged from Egyptology to studying ancient Greek vases and to British prehistoric archaeology. In his old age, Wilkinson settled with his wife in Brynfield House in Gower, South Wales, where he died in 1875 . played a valuable part in the decipherment of Egyptian hieroglyphs; see Thompson, Wonderful Things, 109-128. 
Wilkinson's most enduring legacy, one still relevant for today's scholarship, are his notes and sketches. They are now kept in the Department of Special Collections, Bodleian Libraries, Oxford, under the name "Papers of Sir John Gardner Wilkinson." ${ }^{5}$ This vast archive consists of almost 350 different documents, including notebooks, sketchbooks, maps, plans, leather satchels, and loose papers, spanning from his early years to the last days of his life. Even for today's standards, Wilkinson's notes are surprisingly accurate and still relevant for contemporary researchers as they are often the only source of information on the monuments that have been since long damaged or destroyed in the decades after Wilkinson's visit. ${ }^{6}$ Not just for Egyptology, the archive is of immense importance for anthropology, history, geography, zoology, and biology of Egypt as well as of the Balkans, Wales, Greece, Syria and other countries to which he traveled.

During his several trips between 1823 and 1826, Wilkinson visited the principal monastic sites in the Eastern Desert. He first visited the area in 1823 as part of James Burton's expedition, followed by at least two more (self-organized) trips in 1825 and 1826 . The notes from the journey in 1823 were partially published in the article entitled "Notes on a Part of the Eastern Desert of Upper Egypt" (1832) in the Journal of the Royal Geographical Society. His last two trips, however, remain unpublished, but they were thoroughly documented in several versions. The notes and sketches he produced during these two trips are now located in his archive.

\section{BURTON'S AND WILKINSON'S JOINT EXPEDITION TO THE EASTERN DESERT IN 1823}

According to Wilkinson, the 1823 expedition (which was led by James Burton) started from Cairo and traveled from Beni Suef, a town on the western side of the Nile, towards the Red Sea coast.

The complete catalogue of the Sir John Gardner Wilkinson archive is accessible online at the Bodleian Libraries website.

6 Unfortunately, Wilkinson's manuscripts are extremely difficult to read, which is often also due to circumstances in which he produced his notes as, for example, writing them on horse- or camelback. See Thompson, Sir Gardner Wilkinson, 103.

7 Wilkinson also traveled to the Balkans (including present-day Slovenia) in 1844. He subsequently published his travels in a monograph entitled Dalmatia and Montenegro (1848). Numerous notes and drawings from this journey are still accessible in the archive. 


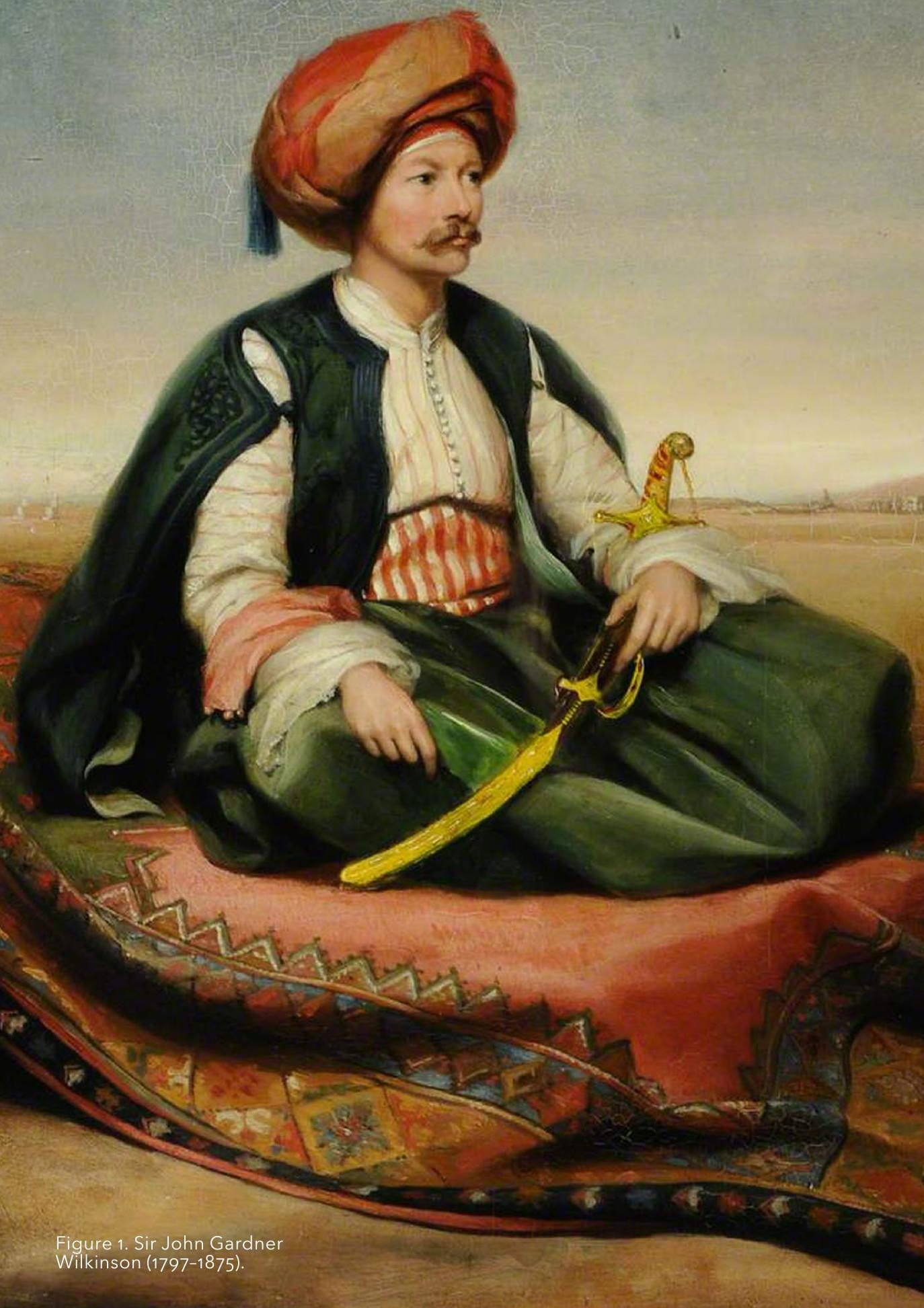




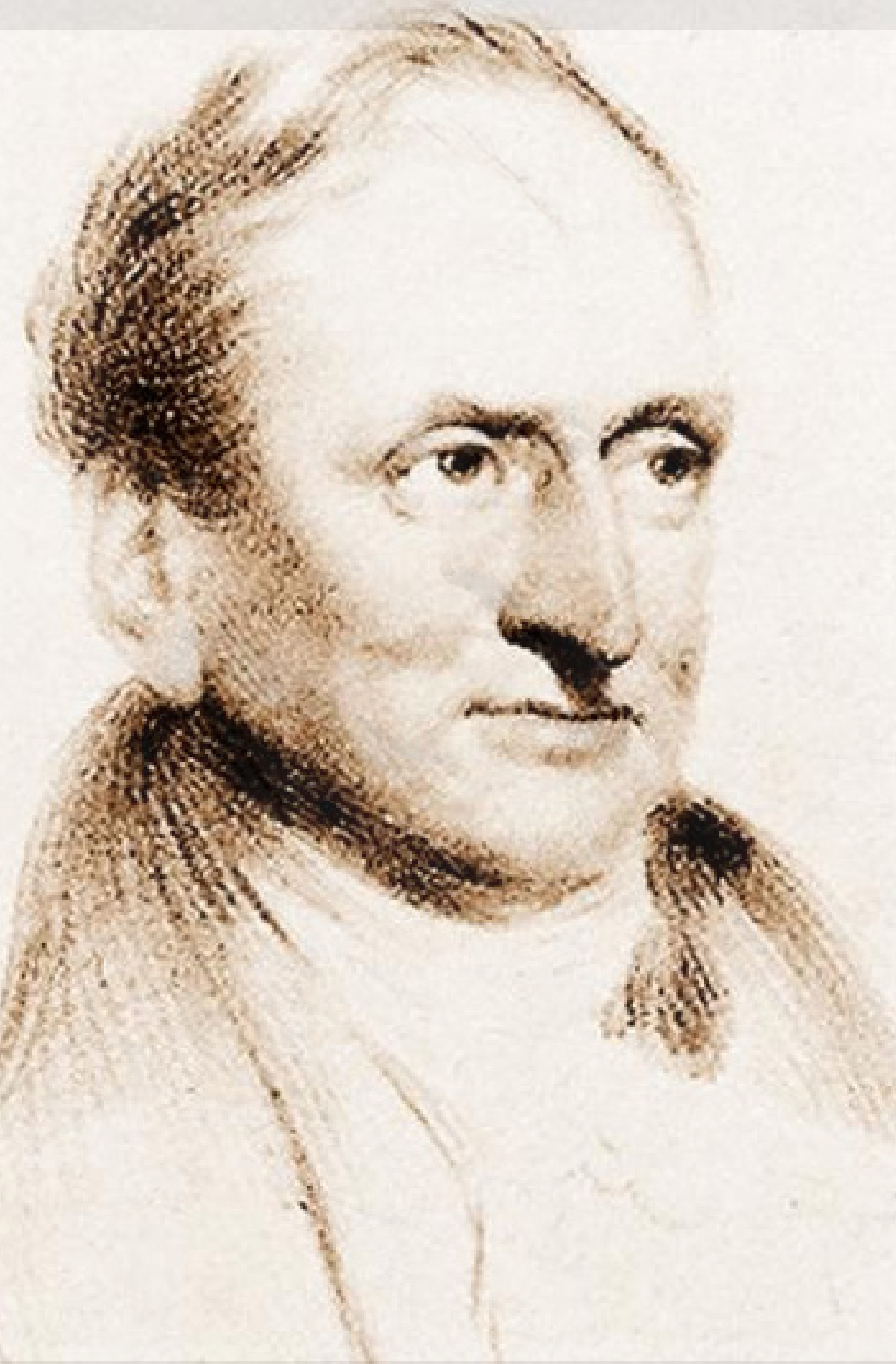


The path led through the vast plain of Wadi Arabah, located in the northern part of the Eastern Desert, stretching between the modern town of Kureymat (in the Nile Valley) in the West and the town of Za'farana in the East (on the Red Sea coast). The historical epicenter of monasticism in Wadi Arabah has been St. Anthony's monastery, from where the hermits spread to the remote wadis along the Northern and Southern Gallala escarpment. The (semi) anachoretic establishments in Wadi Arabah together with other monastic settlements around St. Paul's Monastery and the Red Sea coast between Ayn Sukhna and Za'farana formed a geographically unified monastic desertscape, known in ancient sources as the "Mountain of St. Anthony." ${ }^{8}$ Since the (semi)anachoretic settlements were located around the few permanent water sources in the area, the caravans traveling from the Nile valley to the Red Sea frequently stopped there, offering Wilkinson the opportunity to visit and inspect these sites (figure 3).

On the way to St. Anthony's monastery, the caravan thus stopped in Wadi Um Innaba, located at the northern footslopes of the South Gallala mountain range. ${ }^{9}$ This fork-shaped wadi housed a small semianachoretic community. Close to the water source in its western branch, marked by a small palm grove, still lie the ruins of the hermitage. It is presumably this hermitage that Wilkinson mentions in his article:

At Gebel Annaba we stopped for water; there are two very good springs, three or four miles from the plain; near each of which is one old deserted house, probably built by the monks of the neighbouring convent. The ravines are very fine and bold, and, judging from their depth, much water must fall there in the rainy season. The distance from thence to Deïr Antonios is little less than twelve miles. ${ }^{10}$

A built structure that was not mentioned in Wilkinson's report, however, was the largest and best preserved of the hermitages in the Wadi Um Innaba, which is located on the rocky hillslopes of its eastern branch.

8 Martin, "Les ermitages d'Abou Darag," 185.

9 For later reports see Fontaine, "Le monachisme Copte et la montagne de Saint Antoine.”

10 Wilkinson, "Notes on a Part of the Eastern Desert of Upper Egypt," 29. 
Furthermore, Wilkinson reported on another anachoretic site at Bir Bikheit on the northern side of Wadi Arabah, even though he did not explore it personally: ${ }^{11}$

From St. Anthony we crossed the Wady Arabah, in the direction of Deïr Ebkhéit, or Bekhéit, about N.E. by N. Having heard that near that spot were some old copper-mines, we resolved on visiting them, in preference to the watering-place itself, where we understood there was nothing but a few palms, and not even any remains of a convent; though I have no doubt, from the name, that the place was once the abode of monks, as well as many others in these mountains, which bear the same prefix. ${ }^{12}$

For some time, the expedition stayed in St. Anthony's monastery and then continued towards St. Paul's monastery. During this time, both Wilkinson and Burton produced several watercolors and sketches of the monastery (figures 4-9).

After leaving St. Paul's monastery, they carried southwards and visited the site that Wilkinson called "Wady Ghrásheca" (or possibly Ghrasheea), where he found several inscriptions, some of them probably of monastic origins. The exact location of "Wadi Ghrásheca" is today unknown. Wilkinson writes the following:

\begin{abstract}
A short distance beyond is Wady Dtháhal, at the end of which is a spring of good water bearing the same name. We passed some rocks of micaceous schist approaching to gneiss, and a little farther on the junction of the primitive and grit-stone, from which we descended to the Wady Ghrásheca. Here we found some scratches on the rocks, and two or three Greek words and names. ${ }^{13}$
\end{abstract}

From there, the expedition continued southwards to the ancient Mons Porphyrites (Gebel Dukhan) and Mons Claudianus area. There, Wilkinson surveyed the church of a semianachoretic settlement in Wadi Naqqat, located about $55 \mathrm{~km}$ west from the city of Hurghada at the Red Sea. ${ }^{14} \mathrm{He}$ described the path to the site and its surrounding as follows:

11 For later reports see Ghica and Tristan, "Bir Bihīt: Preliminary Report on the 2012 Field Season." Wilkinson, "Notes on a Part of the Eastern Desert of Upper Egypt," 31.

13 Wilkinson, "Notes on a Part of the Eastern Desert of Upper Egypt," 38.

14 For the general description of the entire settlement see Ciglenečki, "The Laura of Wadi Naqqat in the Eastern Desert" (forthcoming). 
The beautiful valley which leads to the water of Guttár, is filled with fine seyáles, which at this time were particularly green, in spite of the want of rain; on continuing further up the valley gradually diminishes in breadth, and presents the rugged appearance of a mountain torrent's bed, filled with large stones, till it terminates in a precipitous rock, overgrown with hanging water-weeds, down which the water drops slowly; below are palm-trees and rushes, and a basin which affords a plentiful supply of excellent water on digging a hole in the gravel of decayed granite, with which it is filled. There are innumerable figures scratched upon the rocks on the road to the water, and among them is an old tomb, probably Christian. I ascended the rock, and crossing the ravine above, in which were some smaller natural reservoirs, arrived at a stone building, which, from its appearance, is not very ancient: it consists of three rooms, and a kind of portico, or covering, supported on two pillars; nothing but roof is wanting - the walls, windows, and doorways being all perfect. The Arab shiekh, my guide, at length pointed out a 'written stone' which proved to be a Greek inscription (...). ${ }^{15}$

This inscription mentioned by Wilkinson reads: "Flavius Julius, the most eminent leader of the Thebaid, built here a public church, at the time when Hatres was the bishop of Maximianopolis."16 The approximate dating of this commemorative inscription is based on a letter of St. Athanasius to Sarapion of Thmuis from 339 AD. In this letter, St. Athanasius mentioned that Hatres, the bishop of Maximianopolis, had died that same year. Hence, $339 \mathrm{AD}$ is the latest possible dating of the construction of the $\operatorname{church}^{17}$ (even though Wilkinson wrote that the church does not seem very ancient). The church in Wadi Naqqat, therefore, predates the earliest foundation of the more famous St. Anthony's and St. Paul's monasteries.

Wilkinson's subsequent trips to the Eastern Desert in 1825 and 1826 (without Burton) are equally crucial for the research of monasticism in the area. Although he did not publish the material gathered during these two expeditions, his notes, sketches and maps are preserved in his archives. The most important documents (regarding the present discussion) relate to his survey of Dayr Abu Daraj, a large 


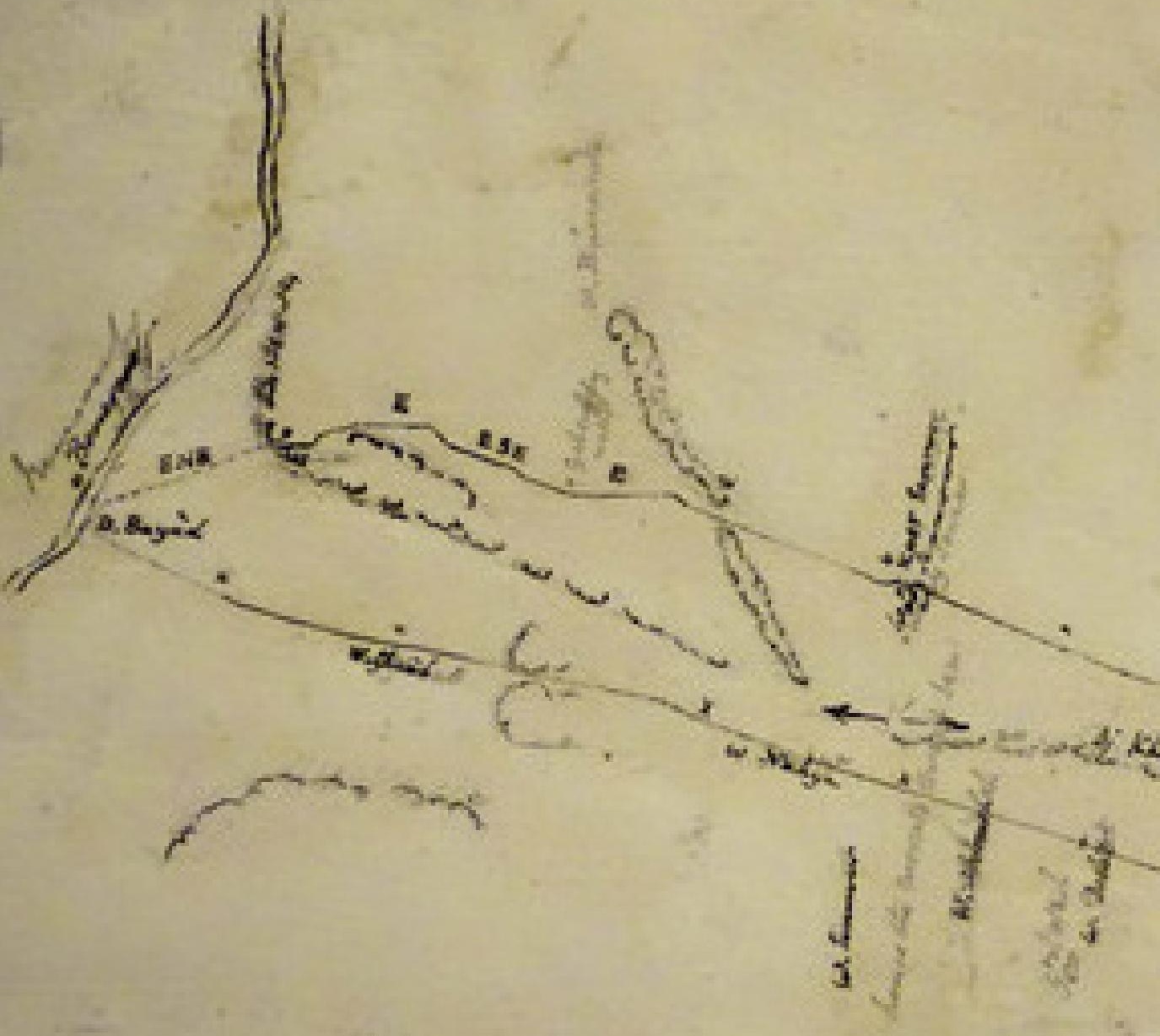


monastic complex with a surrounding semianachoretic settlement, located on the Red Sea coast between the modern towns of Ayn Sukhna and Za' farana.

On the grounds of epigraphical and ceramological studies, the monastery and the semianachorite settlement could be dated to the late 6 th century and the first half of the 7 th century AD. ${ }^{18}$ The most prominent hermitage of the entire laura had numerous graffiti, dipinti, and decorative elements. On the outer side of the hermitage stood a sandstone with Greek and Coptic inscriptions (mainly anthroponyms). Unfortunately, the recent construction of multi-line highways and surging tourist resorts between Ayn Sukhna and Za'farana caused irreversible damage to the historical monuments of laura Wadi Abu Daraj and gave the fatal blow to its most remarkable building. ${ }^{19}$ Regretfully, the site of Wadi Abu Daraj has been previously studied only in parts. Wilkinson's notes, which include a description of the site, a detailed map of the archaeological remains, and some sketches are therefore of immense value for any further study of this important monastic site.

\section{JAMES BURTON AND HIS FIRST EXPEDITIONS TO THE EASTERN DESERT IN 1822 AND 1823}

Although Wilkinson is usually credited as the discoverer of several most important (semi)anachoretic sites in the Eastern Desert, James Burton's role in exploring this area was of equal importance. ${ }^{20}$ Indeed, Burton was a pioneer in many aspects, although his role for the research of monastic history is today much less recognized, also because he never published his findings. ${ }^{21}$ Nevertheless, as the following excerpt from Burton's archival documents demonstrates, he was also interested in the history of monasticism:

21

\footnotetext{
"The Forgotten Egyptologist: James Burton."; cf. Thompson, "Osman Effendi: A
Scottish Convert to Islam in Early Nineteenth-Century Egypt"; and "Edward "The Forgotten Egyptologist: James Burton."; cf. Thompson, "Osman Effendi: A
Scottish Convert to Islam in Early Nineteenth-Century Egypt"; and "Edward William Lane in Egypt."

See Ghica, "Les ermitages d’Abū Darağ revisités," 119, 132.

See Ciglenečki, "Dayr Abu Daraj: Update."

For the life and work of Burton see: Thompson, Sir Gardner Wilkinson; Cooke,

His only publication, Excerpta Hieroglyphica, published in Cairo in four parts (1825-1828) was of importance for the decipherment of hieroglyphs and was known to both Thomas Young and Champollion, two pioneers of decipherment of Egyptian hieroglyphics.
} 
Many proselytes to his example followed him [i.e. St. Anthony] into same desert and succeeding years witnessed the foundation of Dayr Boolos, D[ayr] Abou Déragy or Ohanes(?), Dayr Berkheit, Dayr Barda, Dayr Om Yessin and perhaps many others. Of all these Dayr Antonios \& Dayr Boolos now alone exist - the sites of the others are known only by their ruins and tradition. ${ }^{22}$

It is therefore vital to treat Burton's unpublished archival materials which are now located in the British Library in London ${ }^{23}$ as a relevant source for the history of monasticism in the Eastern Desert - and at the same time to consider his influence on Wilkinson's discoveries.

The story of Burton's exploration begins in the year 1822. When he arrived in Alexandria, he was employed by Muhammad Ali Pasha in order to search for coal, which he hoped could be found in the Eastern Desert. This was his first trip to the area and even though he did not find any coal, he got acquainted with the region and fell in love with it - so much so that he spent most of his time in an encampment there from around $1828-1833 .{ }^{24}$ It was during the first expedition, however, that Burton came across several monastic monuments in the area. Because his first journey took place a year before Wilkinson joined him for his second expedition in 1823, the discoveries described below can be regarded as earlier and demonstrate the seminal role Burton performed as Wilkinson's guide.

Among the discoveries Burton made during this first trip in 1822 was, for example, the early pharaonic site of Wadi el-Jarf near St. Paul's monastery. In later reports, both Burton and Wilkinson mentioned the oral tradition, held by monks living in the nearby St. Paul's monastery, that the site of Wadi al-Jarf (which both identified as "catacombs") was occupied by the penitent monks:

The Monks say also the Catacombs were inhabited by their own people when the Convent was excessively full and the individuals wished to perform severe penitence. ${ }^{25}$

James Burton papers, MSs 25,624, f. 5 .

Catalogue number Add. Mss 25,613-75.

For Burton's life and his duties in Egypt see especially Cooke, "The Forgotten Egyptologist."

25 James Burton papers, Mss 25,624, f. 10. 


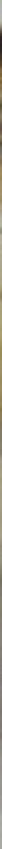

Figure 4. Panorama of St. Anthony's monastery, James Burton papers. Add. MSS 25,628, f. 100. 


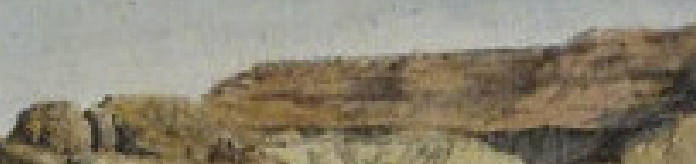

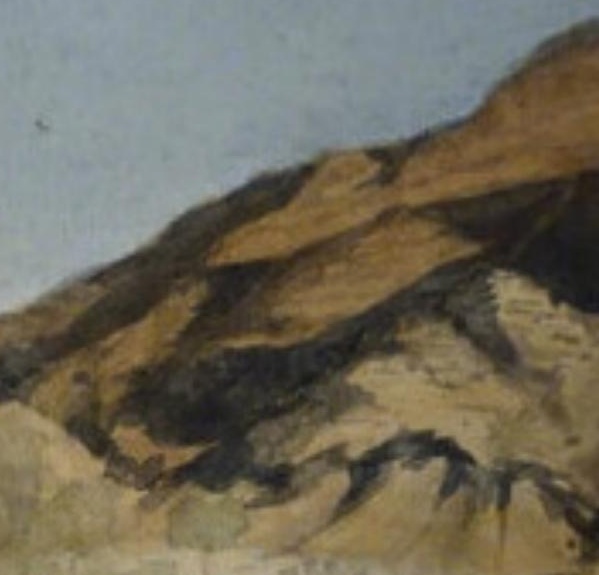

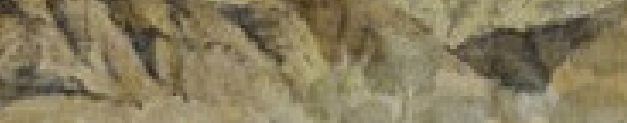

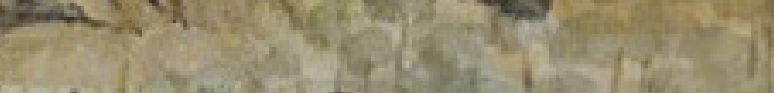

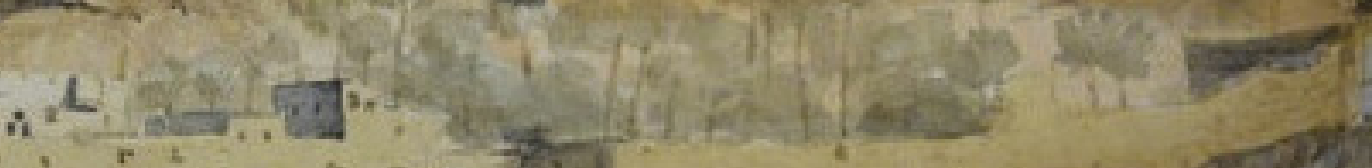

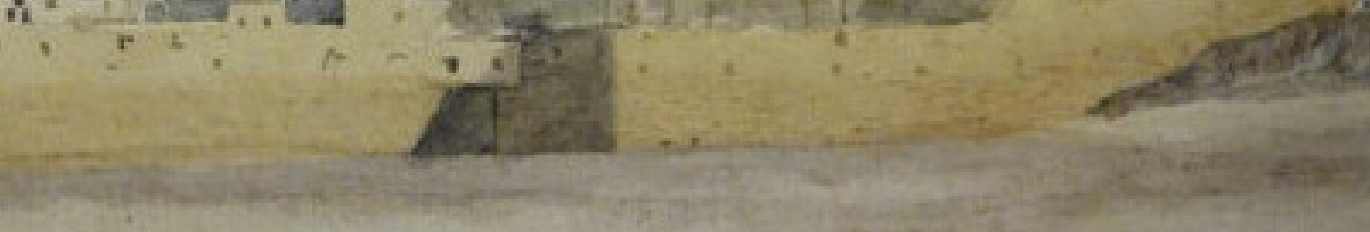





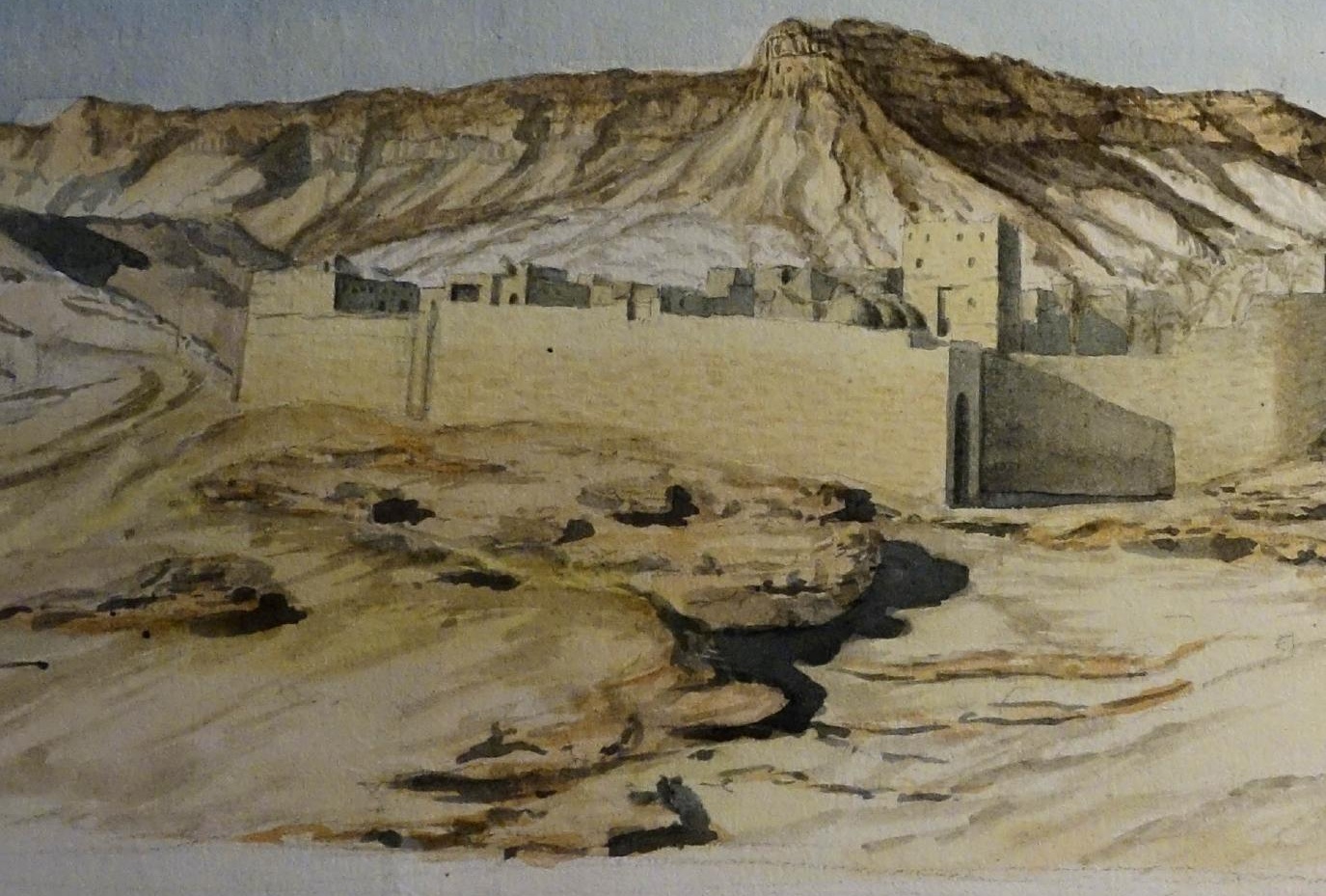

Figure 6. Panorama of St. Paul's monastery, James in Burton papérs. Add. MSS 25,628, f. 107. 


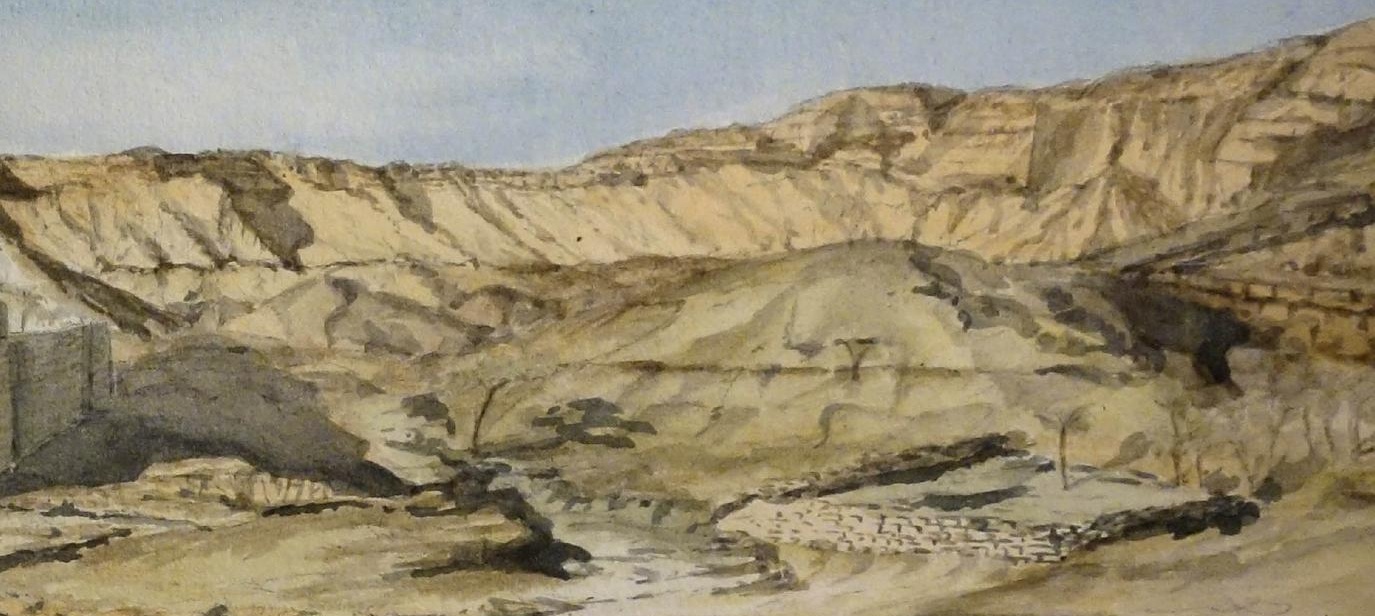

is

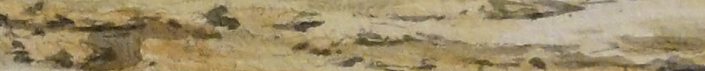
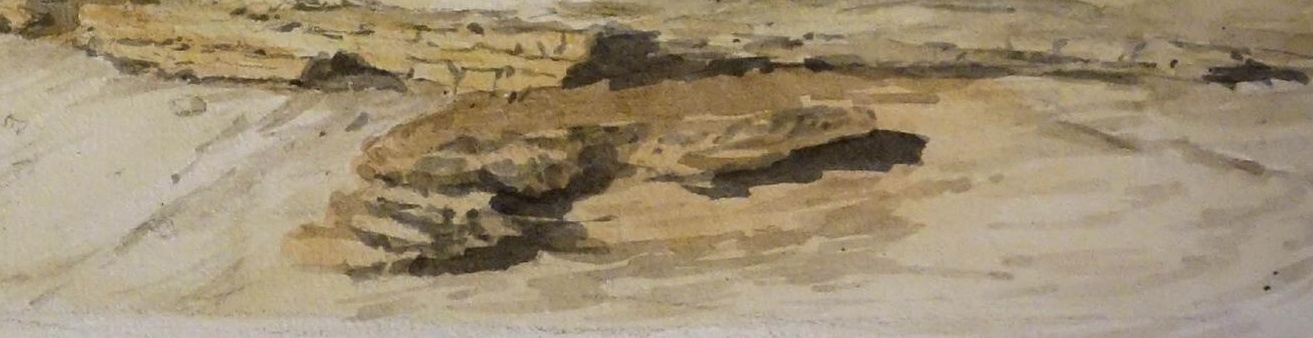


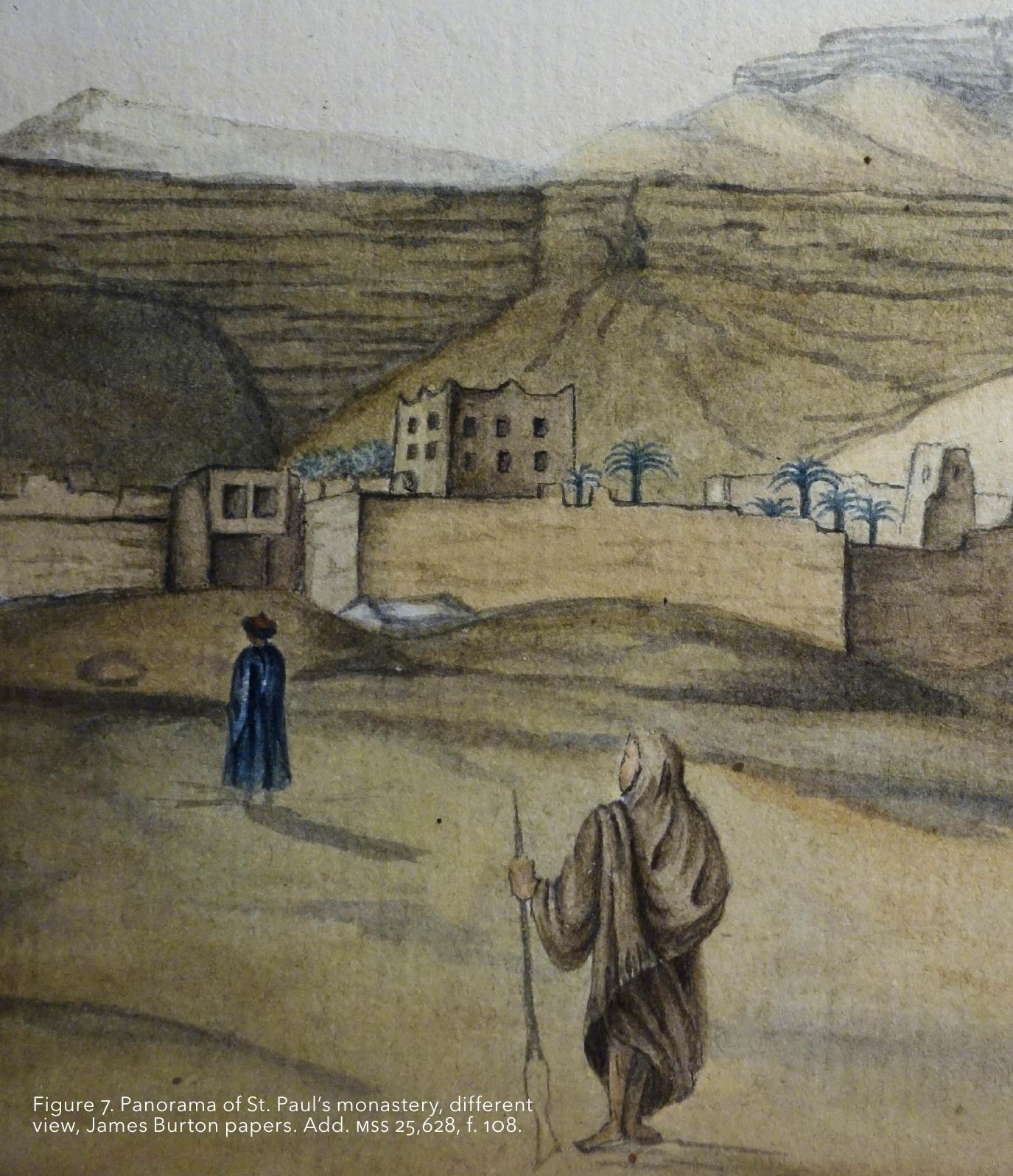




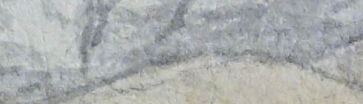
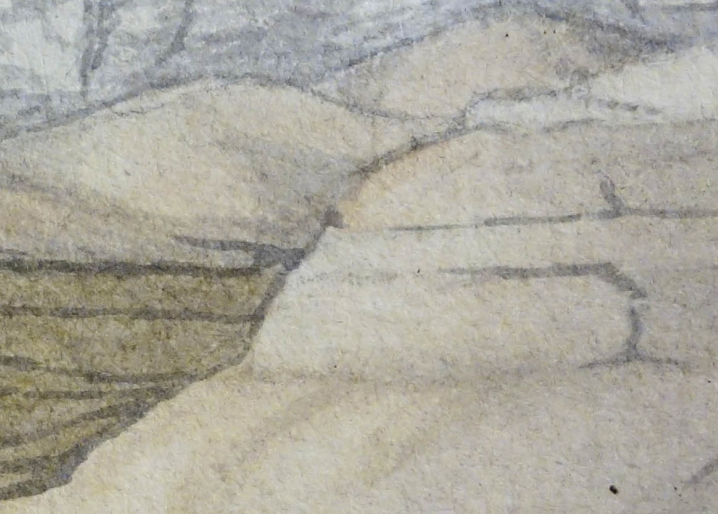

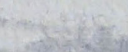

.

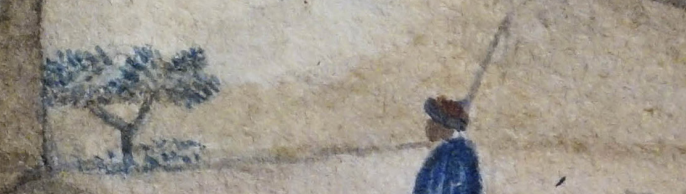

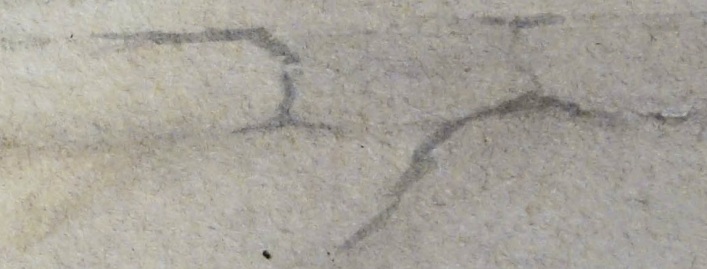

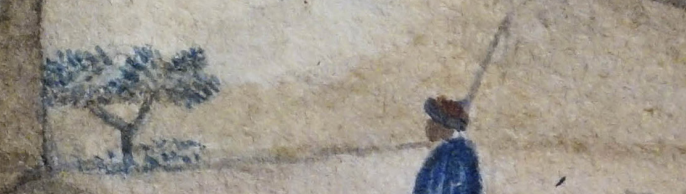
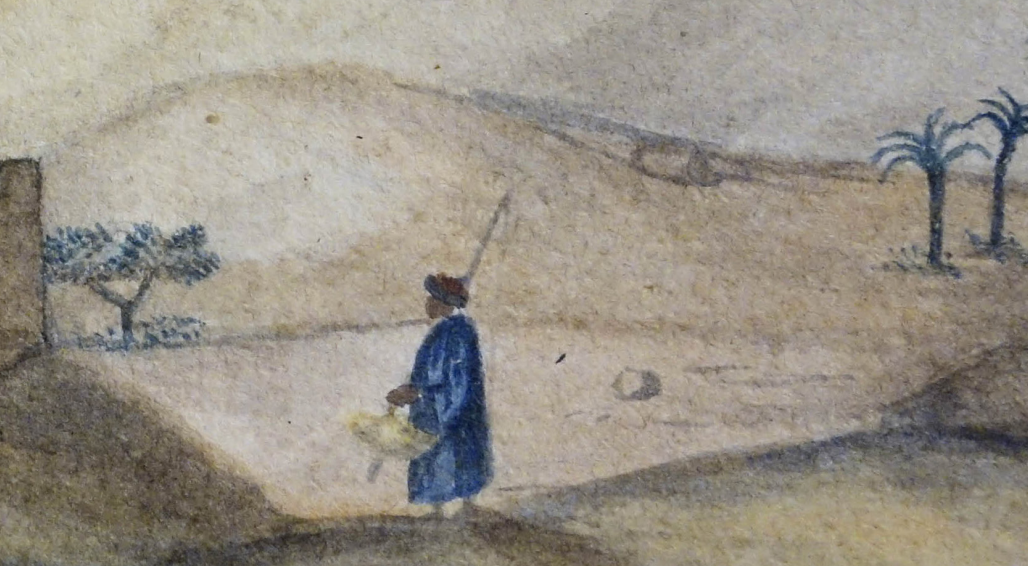

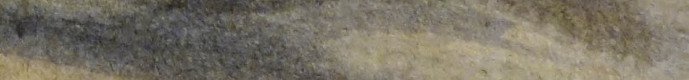

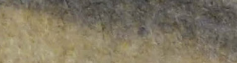




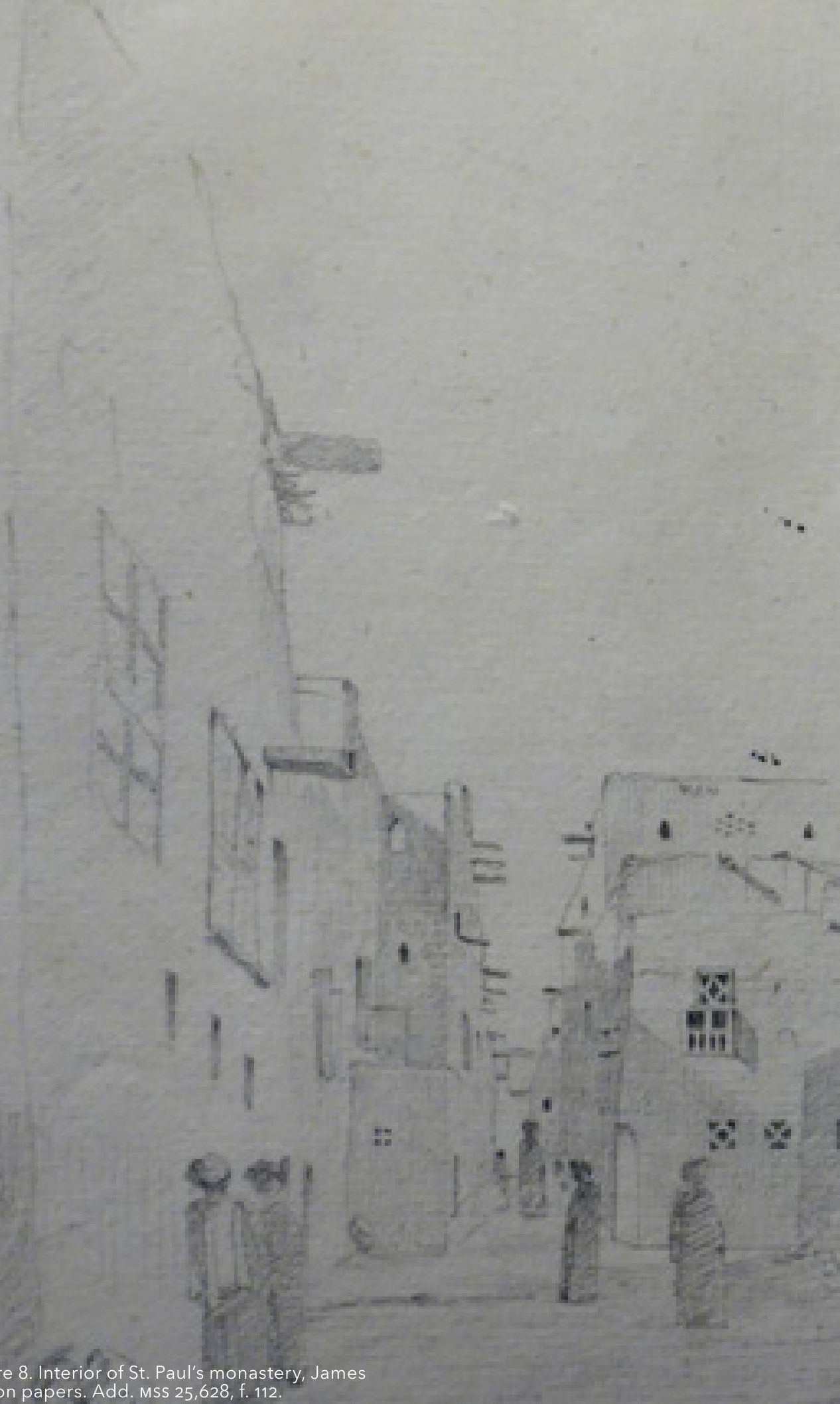

Figure 8. Interior of St. Paul's monastery, James

Burton papers. Add. MSs 25,628, f. 112. 

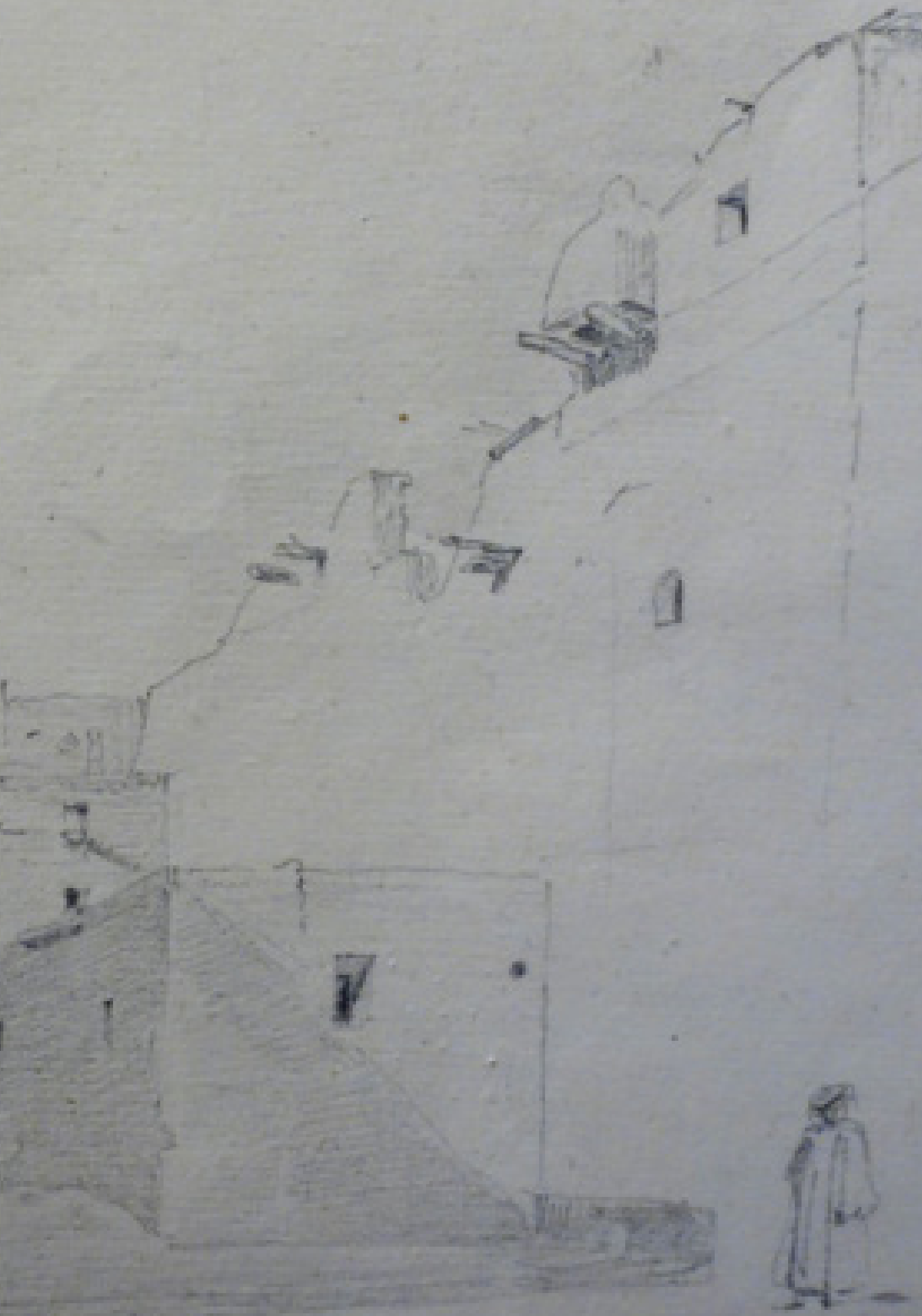


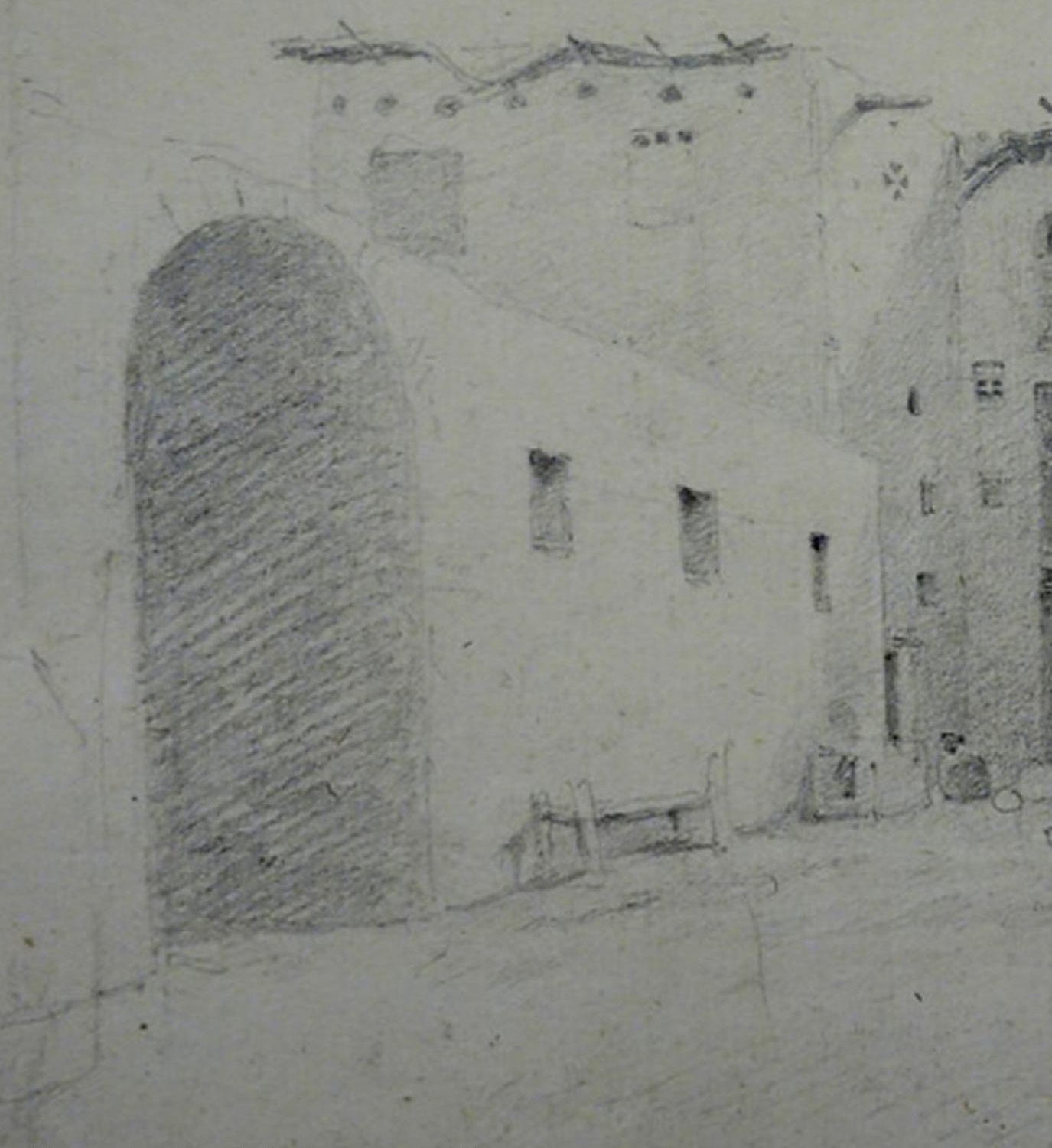

Figure 9. Interior of St. Paul's monastery, different view, James Burton papers. Add. MSs 25,628, f. 110 . 


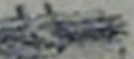

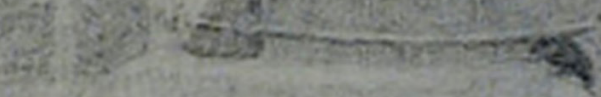

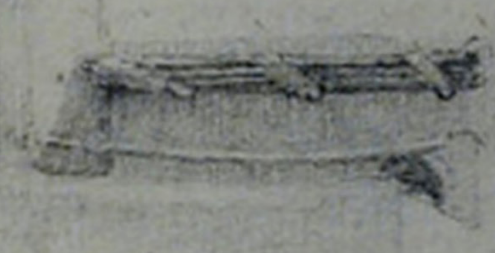

0

tof

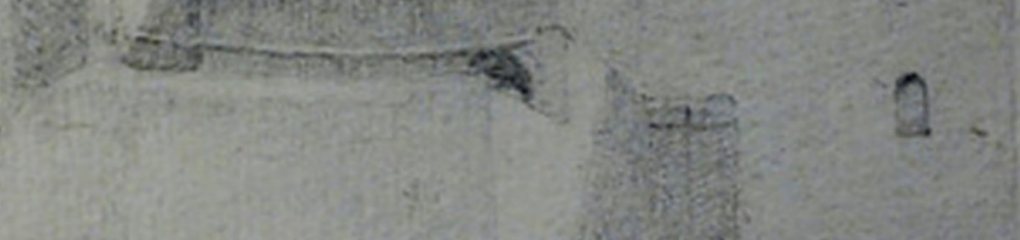

6

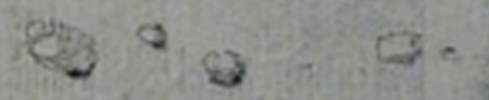

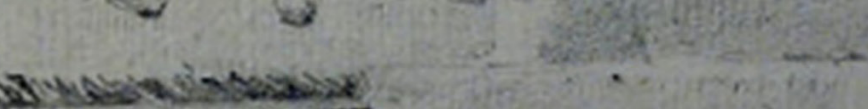

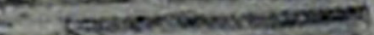

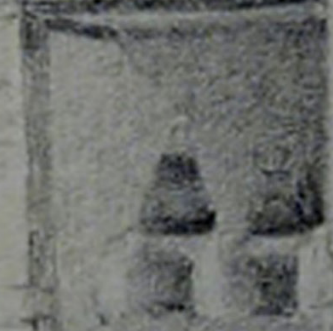

21
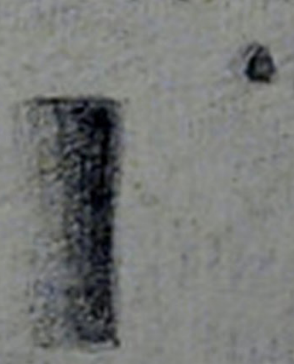

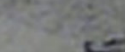

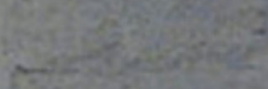

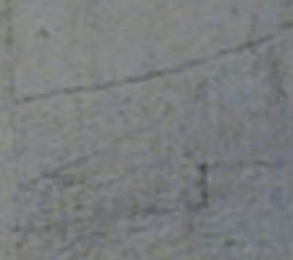

(e) 103

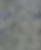

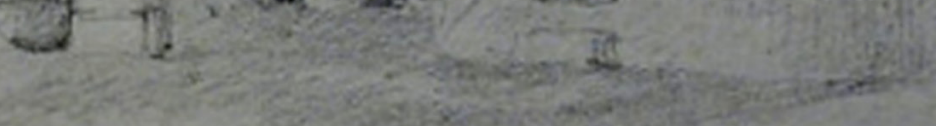

i
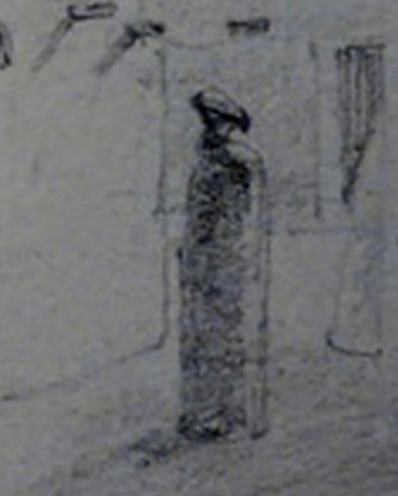

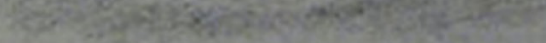


In this context, Burton mentions another archaeological site located above the springs of Wadi Gharib in the area south of St. Paul's monastery, assuming, however, that it is of non-monastic origin:

(...) above the springs of W[ady] Ghareib stand the ruined walls of a building similar in dimensions, which though rough have been too carefully built to be of Hermit or Arab work. ${ }^{26}$

As water sources, Burton mentioned further archaeological sites, which are now considered as possible (semi)anachoretic settlements. Such are, for example, the Wadi Um Innaba and Ayn Barda, about which he wrote the following:

There is water at a place called W[ady] Anaba about 5 miles west of the Convent along the range of Gebel Derr at the foot of the mountain - a good supply. ${ }^{27}$

And:

Nearly opposite G[ebel] Anaba is another called G[ebel] Berda better [sc. water] than Areidy and more - and another behind G[ebel] Berda called Derr Bekheit. ${ }^{28}$

Burton later described Ayn Barda as the original location of St. Anthony's monastery, which was, according to his report, later moved to its present location.

Among other sites which Wilkinson later mentioned in his publication, Burton wrote down the name "Ghrásheea" (maybe "Ghrásheca"), which is hence the first known mention of this site. ${ }^{29}$ In the course of the same expedition in 1822, Burton also visited the remains of Abu Shar monastery located near the modern city of Hurghada. ${ }^{30}$ We can hence assume that Burton discovered all these sites before Wilkinson and very possibly also drew his colleague's attention to them during their second expedition. 
Burton's second journey to the Eastern Desert (in 1823) was much better prepared and was accompanied by a caravan of camels carrying both servants and soldiers. ${ }^{31}$ It was this expedition that Wilkinson joined when traveling to the region for the first time. Burton's archival documents from the year 1823 must be interpreted more carefully as they are most probably mixed with Wilkinson's papers (according to our analysis of the handwriting as well as of the content of the manuscripts). Nevertheless, one can assume that Burton pointed to Wilkinson several monastic sites he had visited or noted during his previous journey. Altogether, Burton mentioned "The five convents" in the area:
Derr Abou Deragy - Ruined
Derr Berkheit - Ruined
Derr Berda - Ruined
Derr Antonios - Flourishing
Derr Boolos - Flourishing ${ }^{32}$

It is also apparent from these documents that the 1823 expedition visited "Antiquities in W. Ghraashiya," 33 probably Ghrásheca or Ghrásheea. In the journal, there is even a sketch of one of the same inscriptions that can be found in Wilkinson's papers. ${ }^{34}$

The discovery of a semianachoretic establishment in Wadi Naqqat is less definite as the handwriting in Burton's papers possibly belongs to Wilkinson and it seems, by the looks of it at least, that a few specific papers were inserted later. ${ }^{35}$ Among Burton's manuscripts, however, there is a rough sketch of the map, which mentions Guttár and a hermitage (figure 10). It is therefore impossible to conclude if they documented the site there together or if Wilkinson just shared his observations with Burton. 


\section{CONCLUSION}

This paper highlights the importance of unpublished archival material of early explorers for the history of monasticism in the Eastern Desert. To this end, it discusses the discoveries of (semi)anachoretic sites by Sir John Gardner Wilkinson and James Burton during their expeditions to the area. Both explorers were among the first to document several important monastic sites, many of which are now completely destroyed, damaged or forgotten. Even though Wilkinson was the first to publish his findings as part of his article in the Journal of Royal Geographical Society in 1832, this paper also argued that it was James Burton who had discovered many of these sites already in 1822 and very possibly pointed them out to Wilkinson a year later during their joint expedition.

Hence, James Burton knew about Ayn Barda, Wadi Um Innaba, Bir Bikheit, Wadi el-Jarf, Wadi Ghrásheca, and Abu Shar before his colleague. It is less certain who first visited Abu Daraj. Although Burton mentions the site in his notes (alongside an undated map of Abu Daraj), it seems that it was Wilkinson who was the first to visit the site. This thesis is partly corroborated by an inscription that was found on one of the rocks in Abu Daraj, reading "Burton" and "Depuy" with the date "1830" written besides. ${ }^{36}$ In Burton's archives, there are also two sketches of Abu Daraj (figures 11-12).

Regardless of the question who first visited the discussed sites, it was Wilkinson who paid more attention to archaeological remains and their documentation (as Burton was focusing more on geology), which eventually makes his unpublished documents and papers more relevant for the research of monasticism in the Eastern Desert. Nevertheless, both archives are of immense importance for further research on the topic. on a Station at Bir Aras; on an Ostrakon from El-Heitaand on Some Ruins at Bir Abou Darag," 64. 


\section{BIBLIOGRAPHY}

Ciglenečki, Jan. “Dayr Abu Daraj: Update.” In Claremont Coptic Encyclopedia - Claremont Colleges Digital Library (2018): 1-40. Available online.

— . "Wadi Naqqat, The Laura of." In Claremont Coptic Encyclopedia Claremont Colleges Digital Library (2017): 1-6. Available online.

- "The Laura of Wadi Naqqat in the Eastern Desert." In Christianity and Monasticism in Alexandria and Its Surroundings and in the Eastern and Western Deserts, ed. by G. Gabra and H. Takla. Cairo: The American University in Cairo Press, 2020. (Forthcoming.)

Colla, Elliott. Conflicted Antiquities: Egyptology, Egyptomania, Egyptian Modernity. Durham, NC: Duke University Press, 2007.

Cooke, Neil. “The Forgotten Egyptologist: James Burton.” In Travellers in Egypt, edited by Paul Starkey and Janet Starkey. London: I.B. Tauris, 2001.

Dawson, Warren R, and Eric P. Uphill. Who Was Who in Egyptology? London: Egypt Exploration Society, 2012.

Fontaine, Alfred-Léon. "Le monachisme Copte et la montagne de Saint Antoine." Bulletin de l'Institut des Etudes Coptes 1 (1958): 3-30.

Ghica, Victor, Sylvie Marchand, and Antigone Marangou. "Les ermitages d'Abū Darag revisités.” Bulletin de l'Institut Français d'Archéologie Orientale 108 (2008): 115-163.

— Season.” Bulletin of the Australian Center for Egyptology 23 (2012): 7-24. Jasanoff, Maya. Edge of Empire: Lives, Culture, and Conquest in the East, 1750-1850. New York: Vintage Books, 2006.

Martin, Maurice. “Les ermitages d'Abou Darag." Bulletin de la Société d'Archéologie Copte 18 (1965-1966): 139-145.

—_. "Abou Darag dans la montagne de Saint-Antoine." Bulletin de l'Institut Français d'Archéologie Orientale 70 (1971): 173-189.

Murray, G. William. “The Christian Settlement at Qattâr.” In Bulletin de la Société Royale de Géographie d'Égypte 24 (1951): 107-114.

Scaife, C. H. O. "Further Notes on Myos Hormos and Tadnos Fons; with Some Remarks on a Station at Bir Aras; on an Ostrakon from El-Heita and on Some Ruins at Bir Abou Darag." Bulletin of the Faculty of Arts 4 (1936): 63-64.

Thompson, Jason. "Edward William Lane in Egypt." Journal of the American Research Center in Egypt 34 (1997): 243-61.

__ . "Osman Effendi: A Scottish Convert to Islam in Early Nineteenth-Century Egypt." Journal of World History 5, no. 1 (1994): 99-123.

- Sir Gardner Wilkinson and His Circle. Austin: University of Texas Press, 1987. 


—_ "Sir Gardner Wilkinson's House at Sheikh Abd El Qurna.” кмT: A Modern Journal of Ancient Egypt 7, no. 2 (1996): 52-59.

— . "The Sir Gardner Wilkinson Papers: An Update." The Journal of Egyptian Archaeology 78 (1992): 273-74.

- Wonderful Things: A History of Egyptology 1; From Antiquity to 1881.

Oxford: Oxford University Press, 2015.

Thompson, Jason, and Robert Lucas. "Sir John Gardner Wilkinson in

Gower." Gower Journal 46 (1995): 1-14.

Wilkinson, John Gardner. "Notes on a Part of the Eastern Desert of Upper

Egypt." The Journal of the Royal Geographical Society 2 (1832): 28-60.

\section{SOURCES}

British Library. James Burton papers. Add. Mss 25,623.

British Library. James Burton papers. Add. Mss 25,624.

British Library. James Burton papers. Add. Mss 25,625.

British Library. James Burton papers. Add. Mss 25,628.

Oxford, Bodleian Library, Ms. Wilkinson dep. Ms. Wilkinson dep. c. 13.

\section{FIGURES}

Figure 1: Sir John Gardner Wilkinson (1797-1875).

Figure 2: James Burton (1786-1862).

Figure 3 Map of Wadi Arabah, James Burton papers. Add. Mss 25,628, f. 50.

Figure 4: Panorama of St. Anthony's monastery, James Burton papers. Add. MSS 25,628, f. 100.

Figure 5: Walls of St. Anthony's monastery, James Burton papers. Add. Mss 25,628 , f. 102.

Figure 6: Panorama of St. Paul's monastery, James Burton papers. Add. Mss 25,628, f. 107.

Figure 7: Panorama of St. Paul's monastery, different view, James Burton papers. Add. Mss 25,628, f. 108.

Figure 8: Interior of St. Paul's monastery, James Burton papers. Add. Mss 25,628, f. 112.

Figure 9 Interior of St. Paul's monastery, different view, James Burton papers. Add. MSs 25,628, f. 110.

Figure 10: Map with marked hermitage in Wadi Naqqat, James Burton papers. Add. Mss 25,628, f. 137.s.

Figure 11: Wadi Abu Daraj, James Burton papers. Add. Mss 25,628, f. 87.

Figure 12: Wadi Abu Daraj, different view, James Burton papers. Add. Mss 25,628 , f. 88 . 


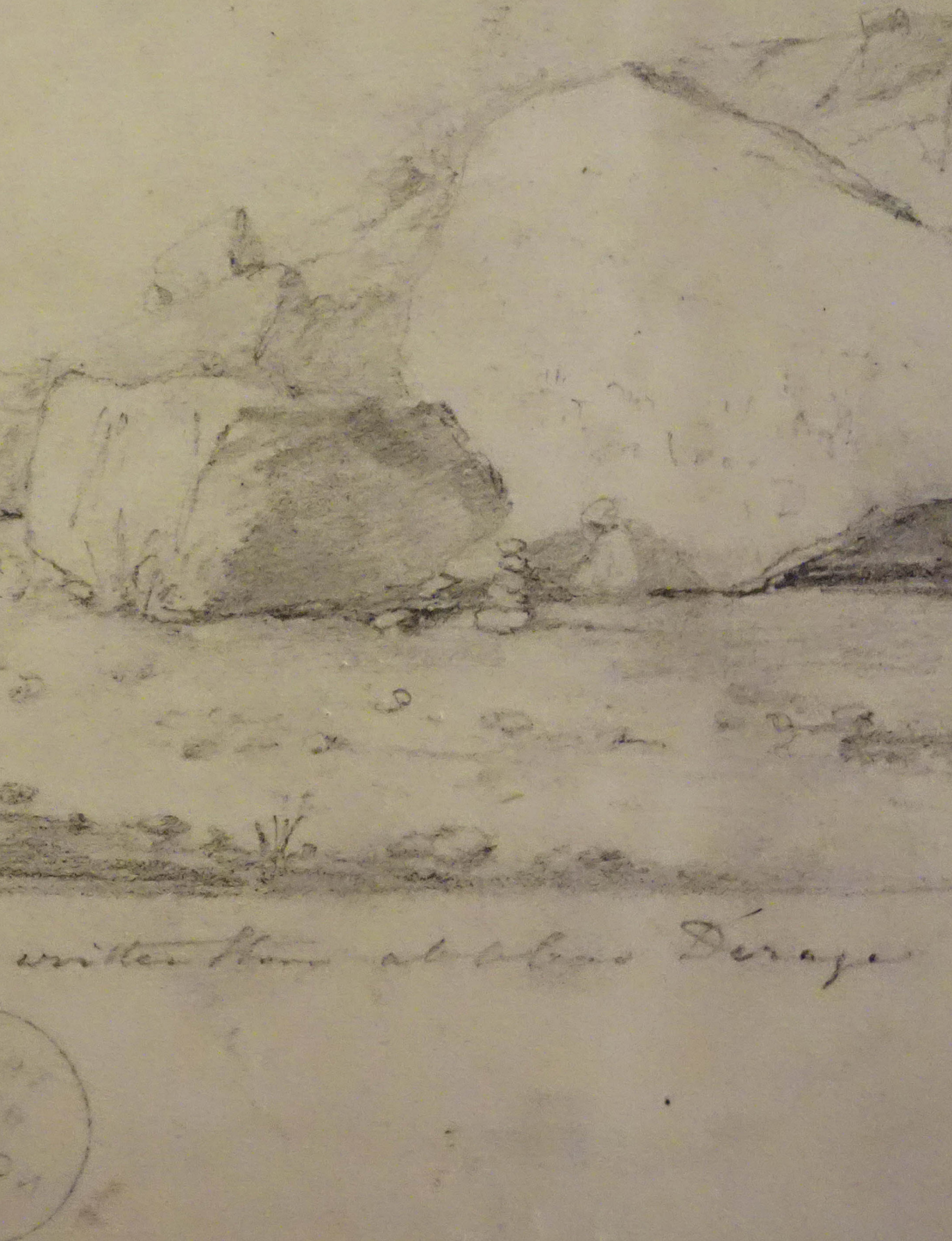

Figure 11. Wadi Abu Daraj, James Burton papers. Add. MSs 25,628, f. 87. 

$+2$

aty

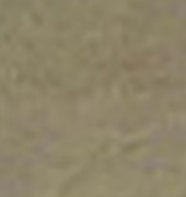

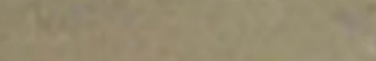

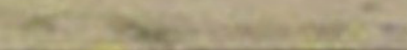

$242+40$

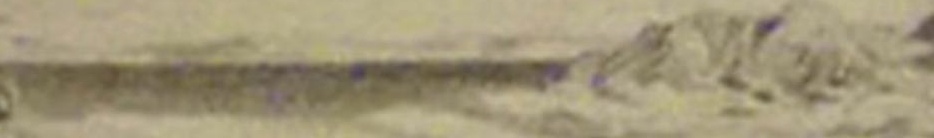

$$
\text { ane }
$$

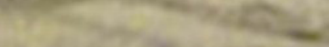

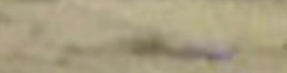

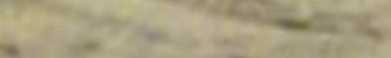

1.

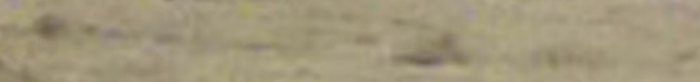

\section{$\frac{2}{8}$}

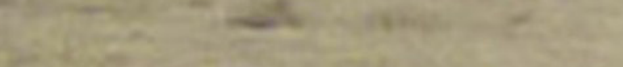




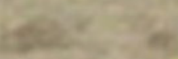

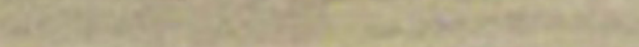

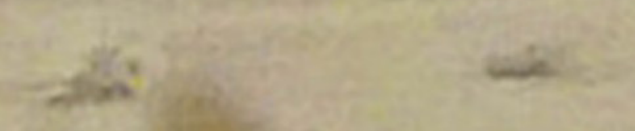

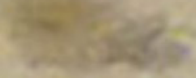

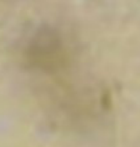

$$
\sin 2 \operatorname{sen} 20
$$

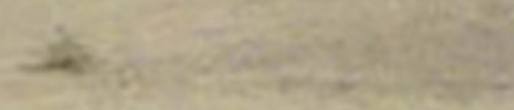

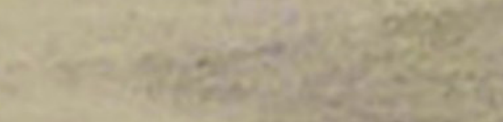

$\sqrt{4}+5$

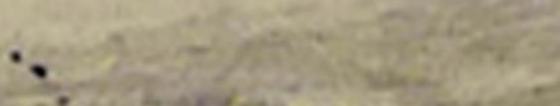

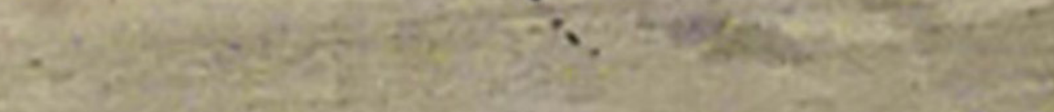

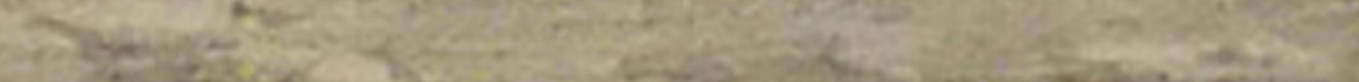



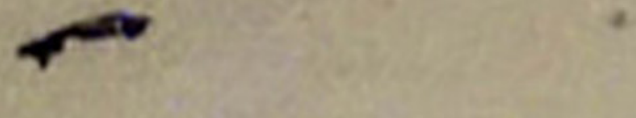

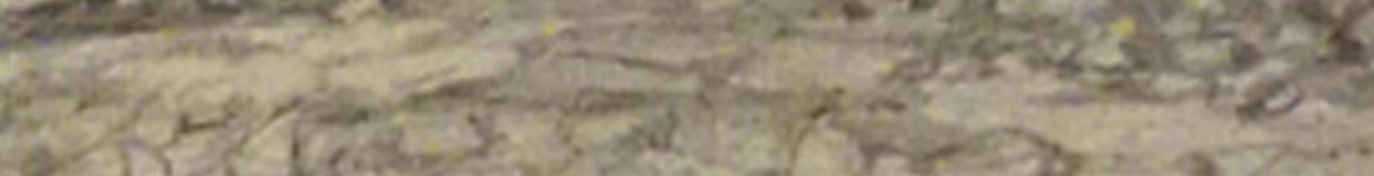
Q

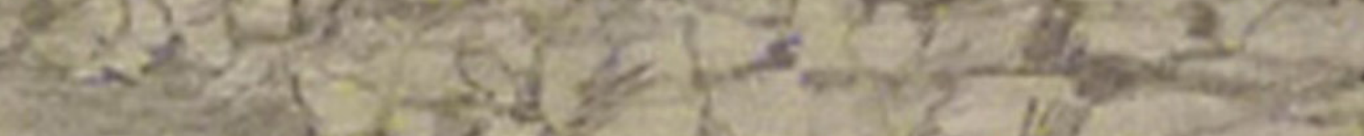

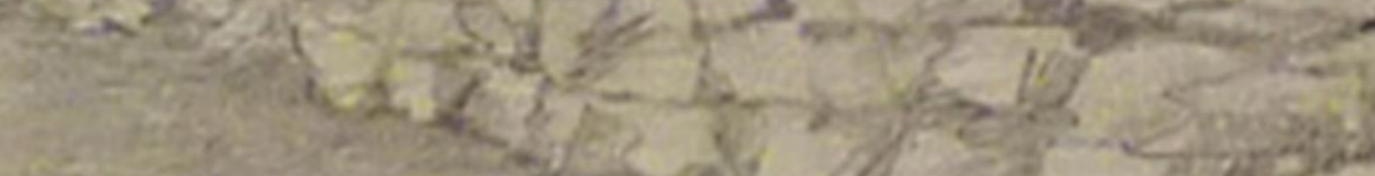




\section{ABSTRACT}

The paper analyzes the personal documents of two early explorers of the Eastern Desert who recorded several monastic monuments in the area: Sir John Gardner Wilkinson and James Burton. The authors argue that these papers are a valuable source for the history of early monasticism as they record many of the monuments now destroyed, severely damaged, or forgotten. It is also suggested that Burton preceded Wilkinson in visiting and documenting some of these archaeological sites, even though Wilkinson was the first to publish them.

KEYWORDS: monasticism, Desert fathers, Archaeology, Egypt, Eastern Desert, Sir John Gardner Wilkinson, James Burton 
PRVI RAZISKOVALCI VZHODNE PUŠČAVE

IN ZGODOVINA MENIŠTVA: SIR JOHN

GARDNER WILKINSON IN JAMES BURTON

\section{IZVLEČEK}

Članek analizira osebne dokumente dveh zgodnjih raziskovalcev Vzhodne puščave, ki sta na tem območju odkrila nekaj samostanskih najdišč - sira Johna Gardnerja Wilkinsona in Jamesa Burtona. Avtorja dokazujeta, da so njuni dokumenti pomemben vir za zgodovino zgodnjega meništva, saj opisujejo številne spomenike, ki so danes uničeni, močno poškodovani ali pozabljeni. Izkaže se tudi, da je Burton nekatera arheološka najdišča obiskal in dokumentiral pred Wilkinsonom, čeprav je ta svoj popis objavil prvi.

KLJUČNE BESEDE: meništvo, puščavski očetje, arheologija, Egipt, Vzhodna puščava, sir John Gardner Wilkinson, James Burton 